Review

\title{
Public and Private Food Safety Standards: Facilitating or Frustrating Fresh Produce Growers?
}

\author{
Jan Mei Soon ${ }^{1, *}$ and Richard N. Baines ${ }^{2}$ \\ 1 Faculty of Agro Industry, Universiti Malaysia Kelantan, 17100 Jeli, Kelantan, Malaysia \\ 2 School of Agriculture, Royal Agricultural College, Cirencester, GL7 6JS, UK \\ E-Mail: richard.baines@rac.ac.uk
}

* Author to whom correspondence should be addressed; E-Mail: soon_jan@umk.edu.my; Tel.: +60-9-573-7933; Fax: +60-9-947-7022.

Received: 14 September 2012; in revised form: 9 January 2013 / Accepted: 9 January 2013 / Published: 22 January 2013

\begin{abstract}
Global private food safety and quality standards have undergone some major overhauls during the past two decades, and these will continue to evolve with the recent emphasis on harmonization. The Global Food Safety Initiative (GFSI) attempts to ensure that harmonize retail standards are commendable and elegant in principle, but in practice, retailers continue to demand their own standard, whilst supporting GFSI's benchmarking program. It is difficult to see such retailers giving up their own standards and the control they currently exert as chain captains. There is also the risk that too much harmonization will result in these standards losing their individuality and uniqueness. Amidst the struggle for private standard dominance, alternative approaches to risk management (e.g., self-assessment of risk, independent audits and risk ranking) may be the way forward, similar to how insurance risks are calculated for businesses. Furthermore, this risk-based approach could also lead to the effective implementation of co-regulation, where both public and private sector compliances are addressed together-a win-win situation. This paper considers the implications and future trends of fresh produce farming, and identifies five interventions (i.e., assurance schemes), which include the do-nothing scenario to underpinning one's brand or label with an existing scheme.
\end{abstract}

Keywords: farm assurance schemes; food safety risk assessment; GFSI; harmonization 


\section{Introduction}

The United Kingdom salad market is growing steadily in response to consumer demands for quick and convenient healthy foods [1]. Fresh vegetable production in the UK has been valued at £1.2 billion [2]. Some of the main fresh crops grown include cabbages, carrots, cauliflower, lettuces, mushrooms, peas and tomatoes [2]. The driving force behind the rapid growth of fresh produce is argued to be the desire of consumers to lead a healthy lifestyle. FAO and WHO introduced the "five-a-day" campaign that encourage people to eat at least five servings of fruits and vegetables daily [3]. In fact, 78\% of the UK population is aware of the five-a-day message, and 58\% claimed consumption of five or more portions of fruit and vegetables daily [4].

The food supply chain is driving each food business operator (from farmers to retailers) to practice due diligence and to ensure that the safety and quality of fresh produce production is not breached. Developing countries are becoming more integrated into the global food market, due to the increase of consumer demand in Western countries for a year-round supply of exotic products and global sourcing from food retailers. This means food industries from developing countries must adapt to the stringent safety and quality standards to gain access into these markets [5].

Prior to the mid 1970s, Cooter and Fulton [6] suggested that food safety was neither a political, scientific or societal concern. The occurrence of microbiological (e.g., Salmonella in eggs), chemical contaminants (e.g., dioxin-contaminated feed) [7] and animal-disease related disease (e.g., Bovine Spongiform Encephalopathy-BSE) and the new variant Creutzfeldt-Jakob disease (nvCJD) food incidents $[8,9]$ have driven both consumer buying behavior and food policy developments [10].

More recently, global food industries have faced different emerging food safety hazard, such as melamine contamination in milk [11], Salmonella serotype Typhimurium in US peanut butter [12], Salmonella serotype Agona in papayas sold in the US [13] and, as previously described, E. coli O104:H4 in fenugreek seeds [14]. This demonstrates that the focus remains centered on produce as a potential source of food poisoning and food borne illness. In response to these public food scares, governments and industries have tightened food safety regulations. The public regulations and private food standards in the EU had undergone some major overhaul during the past 20 years. A number of papers have raised and debated the issue of the public-private food standards' interaction on food industries, especially in the less developed countries [15-19]. Will standards continue to act as barriers for smaller farms and farmers, or could appropriate risk-based models allow them easier market access? Are private food safety standards complicating or facilitating food industries? This paper reviews the public-private food standard trend in the UK and EU over the past 20 years, considers the implications and future trends of fresh produce farming and explores the possibility of co-regulatory coordination between public-private sectors and the various assurance development options.

\section{Public Food Safety Standards: 1990-2000}

Public food safety standards are enacted to protect consumers' health by assuring a safe supply of commodities and to eliminate fraudulent practices [20]. Food safety standards, public and private, are fundamentally about establishing control, conformance and compliance in the production, processing and distribution of food [21]. National governments have the responsibility of establishing the 
standards, legislation and enforcement programs necessary to control food safety and quality. In addition, the food supply chain stakeholders ('industry') have the responsibility for implementing food safety and quality systems to ensure compliance with the standards and legislation [22]. Policy makers also determined that the food industry should accept greater responsibility for the quality and safety of food, whilst food industry stakeholders considered that they should have greater input in the formulation of national regulatory policy [23]. Food safety standards are increasing not only in quantity, but also, in some cases, in stringency and complexity [24,25]. This is due to the establishment of standards at different levels (national, regional and international), which are often not harmonized. Public regulatory initiatives have developed, as shown in the chronological timeline from the late 1970s to 2000s (Figure 1).

Figure 1. Chronological timeline of public regulatory initiatives affecting the EU food system.

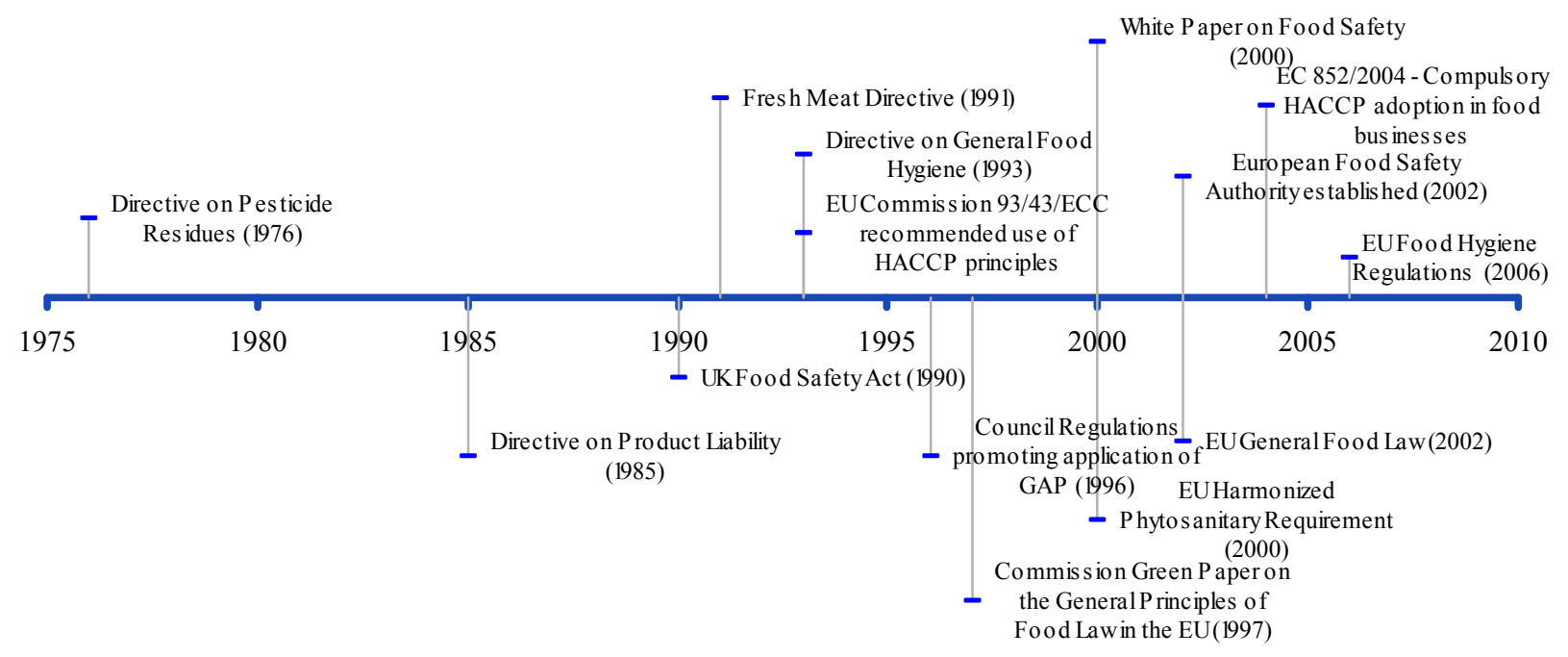

Modified from [4,18,26-28].

\subsection{UK Food Safety Act 1990}

The Food Safety Act 1990 was significant, because it introduced the concept of 'due diligence defense,' which shifted the responsibility for food safety along the whole food supply chain [29]. The critical word in the definition of due diligence is "reasonable". Under this Act, any supplier of a branded product is responsible for the safety of that product. Hence, enforcement could be taken against a wholesaler or retailer even if the offense was caused by other parties in the food chain [30]. However, this is somewhat vague and has encouraged retailers to institute stringent quality assurance programs with their suppliers [31]. The due diligence defense was arguably the first major impetus for the development of private standards [32]. Since the UK Food Safety Act was introduced, retailers were held liable for their private label products-including loose goods, such as fruits and vegetables - unless they had practiced due diligence to ensure the product was safe. Retailers who had previously purchased from multiple and unknown suppliers now needed to know where their products came from and how they were grown [33].

The meat industry was the first to feel the impact, as retailers drew up codes of practice for their suppliers. The industry responded by developing generic farm assurance schemes. The first of these was the Farm Assured Scotch Livestock (FASL), set up in October 1990 [34]; followed by the Farm 
Assured Welsh Lamb (FAWL) and Farm Assured British Beef and Lamb (FABBL) [31]. All of these schemes cover the same critical factors, such as traceability, feeding, animal health, animal welfare and transport and handling [31]. All of the major retailers now require all livestock to come from suppliers who are members of a recognized farm assurance scheme [29]. The UK Food Safety Act 1990 and the ensuing EU General Food Law (2005) have facilitated private standards by holding food business operators accountable for any wrongdoing in the supply chain. Based on the regulatory changes, this is in agreement with Henson and Humphrey [35], who observed that the private standards should not be viewed as distinct from the public regulation, but rather, as the response to the ways in which regulatory controls over food safety have evolved. By limiting public standards to minimum food safety requirements, governments often leave private standards to extend beyond the minimum standards [17]. Moreover, the rapid pace of product differentiation has resulted in government regulatory bodies not being able to keep pace with the latest developments and changing production practices [36].

\subsection{EU General Food Law 2005}

The EU Food Hygiene Regulations, enforced since 1 January 2006, extended the food safety legislation to primary producers. Farmers and growers are still not required to implement a hazard analysis critical control point (HACCP) system, but must follow good hygiene practices and control food safety hazards occurring on farms [4]. The EU Directive 93/43 on the Hygiene of Foodstuffs (2004) states that food business operators shall identify and adequately control hazards at any step in their activities to ensure food safety. It also identifies farmers as food business operators, hence primary production must take the necessary steps to ensure food hazards are adequately controlled. Primary producers who are members of recognized farm assurance schemes are considered to meet the requirements of the legislation, hence resulting in less frequent inspection by local UK authorities [4]. The following schemes have been assessed against the requirements of the hygiene legislation and are considered to meet those requirements:

- $\quad$ Red Tractor Assurance Beef and Lamb Scheme (Formerly Assured British Meat [ABM])

- $\quad$ Red Tractor Farm Assured British Pigs Scheme (Formerly Assured British Pigs [ABP])

- $\quad$ Red Tractor Farm Assurance Poultry Scheme (Formerly Assured Chicken Production [ACP])

- $\quad$ Red Tractor Farm Assurance Combinable Crops \& Sugar Beet (Formerly Assured Combinable Crops Scheme $[\mathrm{ACCS}]$ )

- $\quad$ Red Tractor Farm Assurance Fresh Produce Scheme (Formerly Assured Produce [AP])

- Genesis Quality Assurance (GQA)

- $\quad$ Farm Assured Welsh Livestock (FAWL)

- $\quad$ Northern Ireland Beef/Lamb Farm Quality Assured Scheme (NIBLFQAS)

- $\quad$ Scottish Quality Cereals (SQC)

European food policy underwent the first period of harmonization through vertical legislation (e.g., standards of composition), followed by a second period of harmonization through horizontal legislation in the 1980s. There was then a third and new phase of EU food law in the 2000s. Regulation (EC) No 178/2002 set the general principles of food law and established an independent European 
Food Safety Authority [37]. These standards not only deal with food safety concerns, such as pesticide residue and food additives, but also include product quality and social and environmental issues [17,38]. The food sector has reportedly become the third most regulated sector in the EU since (after automobiles and chemicals) [39].

\section{Public-Private Food Safety Standards: 2001-2011}

Giovannucci and Reardon [40] define standards as "defined parameters that segregate similar products into categories and describe them with consistent terminology that can be commonly understood by market participants". The term private standards is used here to describe food and farm assurances that have been developed by interested parties (e.g., producers, food industry sectors, manufacturers, retailers and non-governmental organizations) with the specific purpose of providing sets of rules for the production and packaging of fresh produce. The private standards applied here can be independently checked to assure that the products met the conditions laid down in that standard [41]. Private standards can be divided into two categories: collective standards (e.g., SQF codes) and retailers' specific standards (e.g., Tesco Nurture). Standards can be either pre-farm gate or post-farm gate [42] (Table 1).

Table 1. Public and private food safety and quality standards ${ }^{1}$.

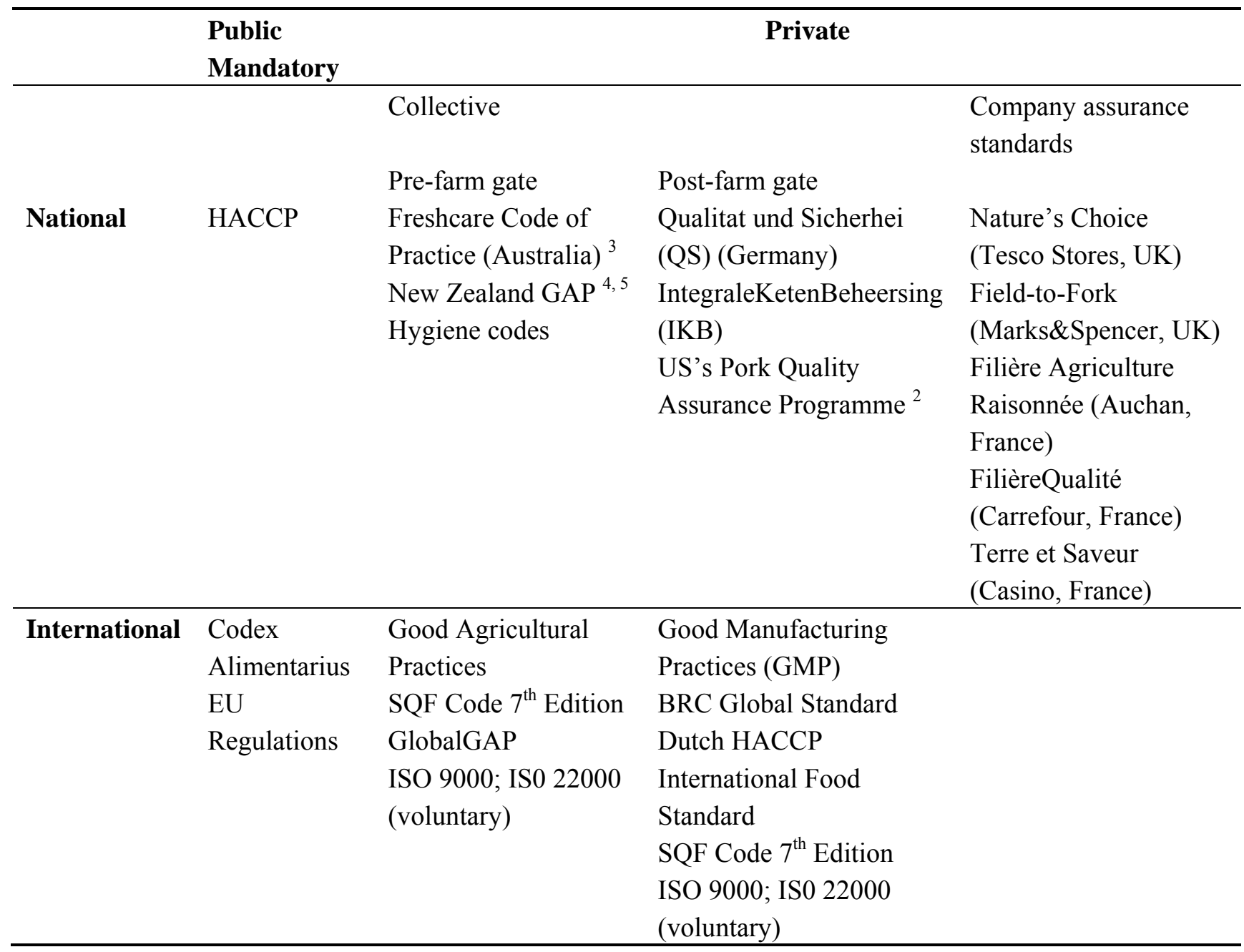


Private standards are frequently categorized as going beyond the requirements of public standards, as reported by Henson and Humphrey [46]. First, private standards are usually seen as more stringent than public standards. Secondly, private standards' coverage is extended vertically and horizontally, where vertical coverage means extending the span of control up and down the chain (farm to fork), while horizontal coverage includes additional elements, such as environmental and social impacts. Third, private standards are much more specific and prescriptive about how to achieve the outcomes defined by the standards. On the other hand, public standards, such as the EU legislation, stipulate legal requirements, but do not specify how to meet those legal standards [30]. Private standards could complement already developed public regulation or act as a substitute for weak or missing public regulations [47]. The impacts of private food safety standards generates different views, where at one extreme, they are seen as reducing the competitiveness of developing countries [48,49] and marginalizing smallholders and decreasing their opportunities for livelihood developments [50,51]; while at the other end, they are considered catalysts for upgrading food safety and quality level and enhancing market competition [32,52].

Retailers and food services are the main interfaces with consumers and are the stages in the food supply chain that are exposed to the greatest liability [41]. The UK food industry is driven primarily by its domestic market, with the supermarket retailers enjoying considerable market power [29]. Ninety-two percent of consumers surveyed by the Food Standards Agency bought most of their household food from supermarkets [53]. This shows that the power in the food sector in developed and emerging economies has shifted from manufacturers and producers to retailers [54]. UK retailers play a significant role in influencing food production in the UK, but this is often seen as controversial [55,56]. Supermarkets dominant force in the UK retail sector and buying power means that supermarkets have the ability to impose tight requirements on how food is produced [55]. Many retailers have also become multinational, meaning that global food retailing resembles an international oligopoly composed of a limited number of multinationals. This consolidation in the retail sector means that producers faced a limited choice of buyers and retailers. Under this condition, the major brand producers (e.g., Nestlé, Unilever, Kraft, etc.) can remain powerful. In contrast, minor brand producers and non-branded producers (such as fresh fruits and vegetable producers) are obliged to comply with the requirements and conditions set by retailers [3].

Retailers are the key actors in the use of private food standards and driving the food system, even though they claim that it is consumer driven. Firms compete among themselves in national and international markets and attempt to differentiate their products to protect and gain market share [17]. The major retailers are all demanding the same level of food safety based on the adoption of HACCP. They also required specified product quality attributes to be met [41]. Northern [57] argued that private quality assurance initiatives are able to signal safety and credence attributes, hence helping retailers to assure due diligence.

Multiple retailers are driving quality assurance scheme compliance by making it a condition of market access for suppliers [58]. In the U.K., the retailers, notably Marks and Spencer with the Field to Fork codes of practice, are driving the food safety agenda through the development of their own standards. The retailer technologists are the main motivators and educators of suppliers to apply risk management on fresh produce [59]. Private food safety and quality standards that operate alongside regulatory systems, although not legally binding in a regulatory sense, can be de facto mandatory for 
suppliers [46]. De facto mandatory standards arise from market-based competition between actions of private firms. When a particular set of specifications gains market share, it acquires influence, and compliance to the standard becomes critical to gain market access, hence the set of specification is considered a de facto standard [32,43]. An example of de facto standard is Nature's Choice standard of Tesco Stores PLC in the UK, which commands a market share of over 30\% [32].

The UK supermarket chain imposes the most stringent food safety standards [25,35]; it requires third party certification from GlobalGAP, British Retail Consortium (BRC) and, in most cases, other retailers' private food safety standards.

GlobalGAP is the most prominent private standard, requiring producers to demonstrate Good Agricultural Practices (GAP) relating to sanitary, phytosanitary and environmental concerns [21]. In the fresh produce sector, private agri-environmental standards typically cover pesticide use and application rates, traceability, water management, adoption of Integrated Crop Management systems, record keeping and self-inspection, harvesting and packaging and transportation practices. These private standards, developed initially to response to food safety concerns surrounding the potential contamination of fresh produce with pathogens and attempts to reduce pesticide residues, have evolved to embrace wider ethical and environmental concerns. In part, private standards are designed to ensure that producers meet the requirements of public standards. GlobalGAP seeks to ensure that fresh produce production complies with EU regulations on MRLs. However, private standards often 'go beyond' the requirements of public standards [21,60]. For example, in 2007, the German retailer, Metro, unilaterally announced that it would only stock fresh fruits and vegetables with less than $70 \%$ of EU MRLs and would delist suppliers that failed to meet the tighter standard [61].

Fulponi [16] gave an interesting insight into why retailers adopt private food standards. Interviews were conducted on 16 major retailers (e.g., Carrefour, Metro, Tesco, Wal-mart, Woolworths). During the interview, the retailers revealed their main incentives and perspectives in adopting private food standards. Reputation building, maintaining food safety and quality were considered the most important attributes in adopting private food standards. Providing consumers with products that meet quality and safety standards that go beyond the minimum requirements was seen as the main incentive of the adoption of private food standards. This is because food safety failures will damage reputation. Eighty five percent of the retailers reported that their required standards' are higher than that of the government. Other factors include social and labour standards where $50 \%$ of the retailers reported exceeding the minimum standards set by International Labour Organization [16].

This is in agreement with Gulati et al. [62], who reported that super- and hyper-markets in Asia put much emphasis on freshness, product quality and food safety, because the risk of selling 'bad' food is devastating to the supermarket compared to traditional traders in a wet market.

In addition, different companies and groups within the industry have developed their own standards, resulting in the proliferation of private and public voluntary standards in the food supply chain (Figure 2) [63]. As a result, it is arguably private rather than public standards that are becoming the predominant drivers of food safety and quality in food systems [64]. 
Figure 2. Chronological timeline of the proliferation of private food safety and quality standards.

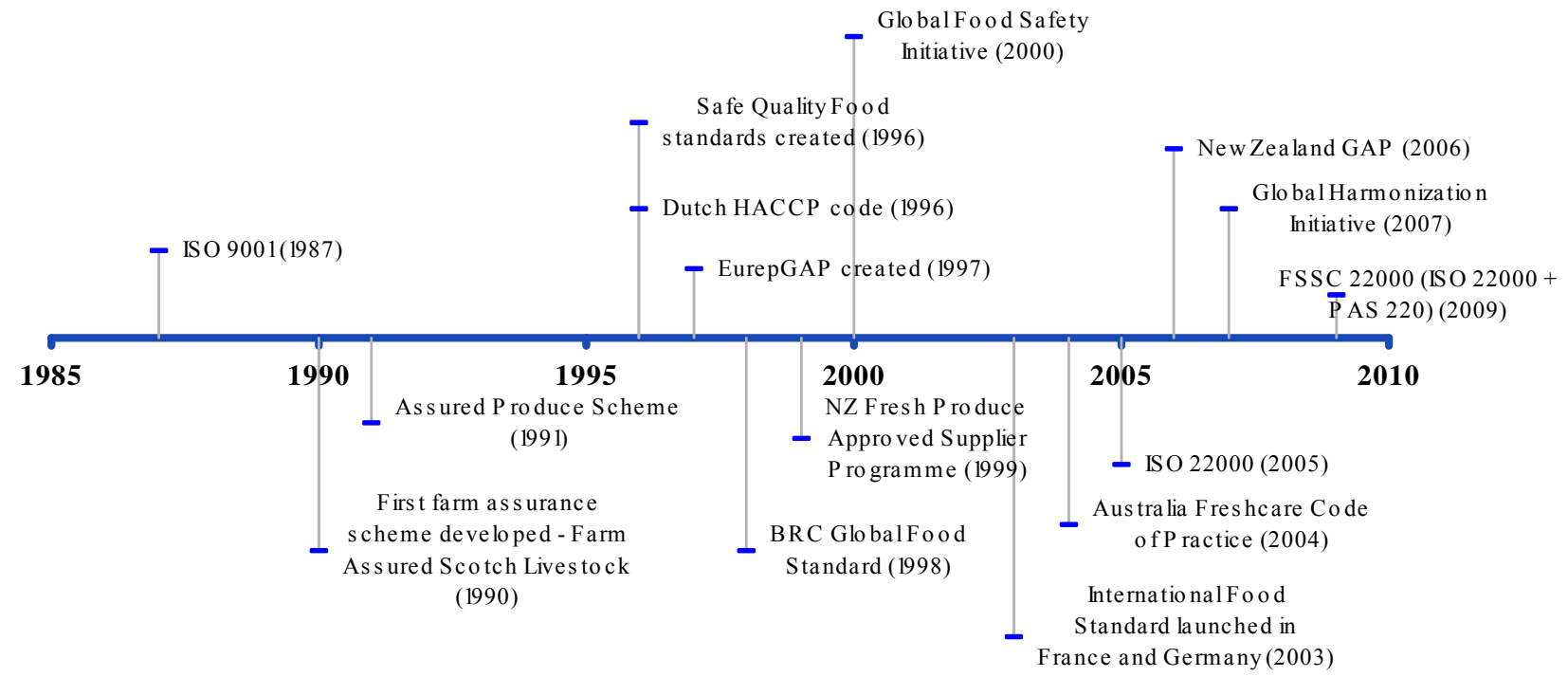

Modified from: [18,26,44,45,65].

\section{Facilitating or Frustrating Fresh Produce Growers?}

The UK fresh produce industry is influenced by a number of different assurance initiatives. Retailers, including Waitrose and Sainsbury, adopt industry-led voluntary schemes, such as the Assured Produce Scheme (APS) in the UK and GlobalGAP accreditation for overseas standards. Individual firms' standards, such as Tesco Nurture and Marks and Spencer (Field to Fork), are mandatory global codes of practice, which are enforced as a condition of trade (Table 2). These standards are applied to both UK and overseas suppliers [66]. Chain captains (such as global retailers and the main brand name food companies), who are the main link between the chain and consumers, are increasingly insisting on third party certification of the private standards they have developed to assure the integrity of the food in terms of food safety management (legal defense) and quality specifications (for market positioning) [41,67]. The term 'chain captain' here denotes the power and influence of such organizations to specify what the whole chain should do, as they have the economic power and influence to do so [68]. Producers can also gain guidance from trade-funded bodies, such as the Chilled Food Association. Farm assurance schemes provide primary production standards for food safety and credence attributes important to consumers. Even though food safety and quality are the major goals, these schemes also have marketing value in product differentiation [66]. On the other hand, the BRC covers the pack house operations and does not extend the standards to the farm level [58]. There are currently 406 suppliers certified to BRC [69].

Suppliers, generally large producers, can afford to implement private safety standards and make the necessary organizational changes and technological upgrades. However, private standards and third-party certification may pose challenges to small—and medium-sized producers [70,71]; they are also costly to develop, maintain and monitor [72]. Retailers also tend to require the use of third-party auditors from industrialized countries, who were viewed to be more competent than auditors from developing countries [73]. Martinez and Bañados [74] stated that there are not many local certifiers in most developing countries and international certification or inspection can be very costly. For example, in 2000, Soil Association Certification Ltd. (SAC) charged individual producers an organic certification 
fee of $£ 200$, plus inspections costs of $£ 350$ per day per inspector, in addition to airfares, accommodation and other expenses [73]. Hence, the investments necessary to implement private standards and third-party certification may result in small-scale farmers being pushed out of markets [42,50]. The Organization for Economic Co-operation and Development (OECD) [75] also reported that the costs to upgrade a farm to meet GAP requirements are the major obstacle. In addition, private food retailers may have no interest in how their suppliers will struggle to comply with the private food safety standards adopted by the firm [21].

Table 2. Examples of food safety and quality assurance programs for fresh produce growers [58].

\begin{tabular}{|c|c|c|}
\hline Standard & Standard-setting body & Status of the standard-setting body \\
\hline Assured Produce scheme & Assured Food Standards & $\begin{array}{l}\text { Private association owned by the } \\
\text { food chain }\end{array}$ \\
\hline BRC Global Food Standard & & British retailer organization \\
\hline GlobalGAP & EUREP & Food retailers association \\
\hline Tesco Nurture & Tesco PLC & Food retailer \\
\hline Field to Fork & Marks and Spencer & Food retailer \\
\hline Farm Biodiversity Action Plans & Sainbury’s Supermarket Ltd & Food retailer \\
\hline $\begin{array}{l}\text { ASDA Brand } \\
\text { (e.g., Good for you!) }\end{array}$ & ASDA Stores Ltd & Food retailer \\
\hline Morrisons "The Best" & Morrisons PLC & Food retailer \\
\hline
\end{tabular}

In the SPS Committee in June 2005, St Vincent and Grenadines, supported by Jamaica, Peru, Ecuador and Argentina, raised their concerns regarding the requirements for exporting bananas and other products to European supermarkets. The issue raised was that GlobalGAP's requirements are stricter than those of the Codex Alimentarius [30], which is recognized by the SPS Agreement as an acceptable reference point for food standards and sanitary measures [3]. However, in response to the complaint about GlobalGAP, the EU argued that it is not in a position to intervene, because private sector organizations reflect consumers' demands [3] and are also considered voluntary.

Exporters can choose to supply to EU's retailers that may pay higher prices, but have strict standards for pesticide residues, requiring HACCP to be implemented in the packing facilities and third-party certification [25]. On the other hand, suppliers can choose to supply to a lower-end wholesale market, where only compliance with public food safety standards is required. Different standards imposed by different sectors or companies will affect market access. However, in the longer term, such lower-end market opportunities are likely to diminish; hence, suppliers will still have to upgrade their food safety management system [76,77]. Henson and Jaffee [77] recognize that standards can act as barriers to trade, but at the same time, the standards can also act as catalysts for the upgrading of food safety management capacity and as a basis for market positioning for their bearers.

\section{Assurance Development Options for Fresh Produce Growers}

Co-regulation coordinates both public and private sectors in the regulatory process towards a win-win situation [78]. For example, the public sector would come up with guidelines for the food industry (rather than new legislation) in addition to providing economic incentives to co-operatives to upgrade 
their quality systems, whilst the private sector and co-operatives will gradually implement a quality assurance system [11].

Co-regulation is promoted as an important strategy to improve the regulatory environment within Europe [79]. Co-ordination of public and private food safety management efforts can result in improvements in the level of food safety at lower cost and the more effective allocation of resources [80]. The concept of co-regulation will include both markets and government-based inspections.

According to Garcia Martinez et al. [80], the level of public intervention may range from no intervention (doing nothing) to direct regulation. In between, there is a range of options, such as industry self-regulation [81,82], voluntary implementation [83,84], co-regulation [85], government provision of information and education (e.g., naming and shaming) and incentive-based structures (e.g., rewarding desirable behavior by the private sector). The authors believe that an understanding of what various interventions (i.e., assurance schemes) deliver will enable fresh produce growers to better evaluate what is right for them. Table 3 identifies five options, including the do-nothing scenario, along with the main advantages and limitations of each option.

Table 3. The main advantages and limitations of five assurance development scenarios.

\begin{tabular}{|c|c|c|}
\hline Options & Advantages & Limitations \\
\hline 1. Do-nothing & $\begin{array}{l}\text { - Reliance on regulatory controls } \\
\text { - No cost to industry } \\
\text { - Product still recognized in country }\end{array}$ & $\begin{array}{l}\text { - Lack of market acceptance of regulatory } \\
\text { controls only } \\
\text { - Domestic market only }\end{array}$ \\
\hline $\begin{array}{l}\text { 2. Develop a } \\
\text { national label/brand }\end{array}$ & $\begin{array}{l}\text { - Recognition of products outside } \\
\text { country } \\
\text { - Ownership of brand and label } \\
\text { - Control over marketing strategy }\end{array}$ & $\begin{array}{l}\text { - Cost of promotion/marketing } \\
\text { - Risks to brand if safety is compromised } \\
\text { - Risk to brand if quality is not controlled }\end{array}$ \\
\hline $\begin{array}{l}\text { 3. Develop your } \\
\text { own assurance } \\
\text { scheme(s) to support } \\
\text { your label }\end{array}$ & $\begin{array}{l}\text { - Control of what is included in scheme } \\
\text { (safety, quality and credence) } \\
\text { - Ownership of assurance } \\
\text { - Underpinning of label/brand }\end{array}$ & $\begin{array}{l}\text { - Cost of development and promotion } \\
\text { - Cost of new scope for certification } \\
\text { - Recognition of scheme(s) by } \\
\text { international markets }\end{array}$ \\
\hline $\begin{array}{l}\text { 4. Adopt an existing } \\
\text { scheme }\end{array}$ & $\begin{array}{l}\text { - Scheme developed and operational } \\
\text { - Lower cost adoption in country } \\
\text { - Scheme recognized by international } \\
\text { markets }\end{array}$ & $\begin{array}{l}\text { - Lack of control/development of } \\
\text { scheme(s) } \\
\text { - No control over costs of scheme(s) } \\
\text { - No country of origin recognition }\end{array}$ \\
\hline $\begin{array}{l}\text { 5. Underpin your } \\
\text { own brand/label } \\
\text { with an existing } \\
\text { scheme }\end{array}$ & $\begin{array}{l}\text { - Recognition in international markets } \\
\text { - Adaptation of scheme(s) to local } \\
\text { requirements/issues } \\
\text { - Country of origin brand underpinned } \\
\text { by recognized assurance scheme(s) }\end{array}$ & $\begin{array}{l}\text { - Cost of development } \\
\text { - Cost of brand promotion } \\
\text { - Reconciling local requirements with } \\
\text { international standards }\end{array}$ \\
\hline
\end{tabular}

The above summary is based on a logical application of the likely costs and benefits of the five scenarios and does not include the politics of assurance schemes. Obviously, individual situations will vary, and it is also important to embrace the political dynamics of trading relationships along specific fresh produce chains. Fresh produce growers need to consider the shorter and longer term options, which will be in part influenced by the requirements to access intended markets for produce and in part by the ability of the fresh produce sector to respond to these requirements. 
Taking the UK as an example, currently, produce growers can expect annual audits linked to their produce private standard (Assured Produce under the British Farm Standard), as well as the possibility of periodic visits from the Rural Payments Agency (for their environmental cross compliance) and Environmental Health (for food hygiene under the EU General Food Law). The consequence is the potential for multiple audits to address both private and public concerns. This is not satisfactory for the producer, as each audit event consumes expensive management time in preparing, hosting and responding to auditors. It is also unsatisfactory for society to have environmental and food hygiene regulations only checked periodically (and in some cases, perhaps never checked). By integrating public and private audit points under one independent certification audit, the costs to producers can be minimized and public confidence should grow due to more frequent auditing. Subsequently, the audit evidence can be separated and sent to appropriate recipients for review. The additional cost of regular public audit could be borne by government (at a lower cost than providing a whole new cadre of auditors) as opposed to industry. Finally, the government could establish a smaller audit team to check compliance of certification auditors and to audit farms that are not part of the private standard.

\section{Global Harmonization of Food Certification}

A large group of internationally operating retailers introduced the Global Food Safety Initiative (GFSI) in 2000 under the initiative of the Food Business Forum (CIES). It aims to facilitate the benchmarking of private food safety standards to reduce the duplication of certification and work towards a vision of "once certified, accepted everywhere" standards [86]. The GFSI Guidance Document [87] established a Benchmark Model to serve as an "equivalency framework". The model identifies three key elements that a food safety standard should contain:

(a) good agricultural or manufacturing practices

(b) a food safety management system

(c) a HACCP system based on or equivalent to the Codex Alimentarius HACCP standard

To date, the BRC Global Standard Issue 6, SQF Code $7^{\text {th }}$ Edition and IFS version 6 have been assessed and recognized as equivalent to GFSI Guidance Document. Canada GAP, Food Safety System Certification (FSSC) 22000, Global Aquaculture Alliance Seafood Processing Standard, GlobalGAP, Global Red Meat Standard and PrimusGFS are still undergoing the benchmarking process (as of November 2012).(GRMS) [88]. Harmonization would decrease certification costs for suppliers and permit retailers to switch suppliers and source easily across the globe [72].

In theory, retailers should accept any one of these standards; however, in practice, retailers still prefer certification against their "own" standards [89]. Firms in a country would support their own standards, because that would raise its rivals' costs more than their own costs. This may effectively make a particular country unable to compete [90]. This raises the question: if global retailers publicly endorse the GFSI initiative (i.e., recognize endorsed standards), then shouldn't there be some form of sanction for those who privately reject endorsed standards?

While many quality characteristics can easily be used by retailers to differentiate their products in the final market, this may not be the case for safety characteristics. Studies by Rozan et al. [91] have demonstrated that consumers perceive safe food as a basic characteristic that they expect and, hence, 
may not be willing to pay a premium. Busch and Bain [92] indicated that retailers prefer to minimize price competition and to compete on the basis of other qualities, such as variety, convenience, quality, consistency, food safety and year-round supply. Some of the food characteristics required by standards are often not intrinsic to the product itself. Consumers cannot be sure by looking if the product has been grown organically or whether labor, trade, environmental and animal welfare standards have been followed [93]. Hence, certification can be used as a signal or trademark to inform consumers of the product quality [94].

It is important to recognize the significant political influences associated with certain standards. For example, many suppliers to the market of a certain country (e.g., BRC Global Food Standard for Great Britain, International Food Standards for Germany and France, Safe Quality Food (SQF) for the USA and Australia) currently have to maintain both BRC and IFS standards to satisfy market access in spite of the CIES agreement of these same retailers to recognize all standards benchmarked under the Global Food Safety Initiative (GFSI). GFSI attempts to harmonize the retail standards are commendable and elegant in principle; but, in practice, retailers continue to demand their own standard [3]. It could be argued that this is an example of the use of economics to protect one's own brand in the European and global markets [41].

\section{Future Trends}

Private standards have evolved over time and will continue to do so. If retailers still continue to stand by their own standards, it is possible to harmonize the risk management approach, while product differentiation will allow retailers to retain their individuality and uniqueness. The costs of compliance are recognized by standards owners and certification bodies, and there exists moves to harmonize audit protocols between the international food standards. Although there are advantages in harmonizing the standards and reducing certification costs for the industry, there is also the risk that too much harmonization will result in these standards losing their individuality, uniqueness and ability to protect individual retail brands. Amidst the struggle for private standard dominance, alternative approaches to risk management (e.g., self-assessment of risk, independent audits and risk ranking) may be the way forward, in a similar way to how insurance risks are calculated for businesses.

Self-assessment of risk may empower both the fresh produce growers and their workers to deliver a safe product. Self-assessment occurs when growers determine the likelihood of potential hazards and evaluate the significance of possible food safety breakdowns at their farms. When growers evaluate the likelihood of contamination and are aware of the serious consequences if no actions were taken, this may compel individuals to carry out risk assessments. The perceptions towards risk assessments may also be motivated by the intention to produce safe food, profit and reputation-building. As such, certification of standards could disappear in favor of a more general risk assessment or inspection for food and farming. Furthermore, this risk-based approach could also lead to the effective implementation of co-regulation, where both public and private sector compliances are addressed together-a win-win situation.

There is also a move within some international certification bodies to promote ISO 22000 for food and farming; hence, reducing the power of global retailers in terms of control over standards. However, it is difficult to see such retailers giving up on their own standards and the control they 
currently exert as chain captains. Amidst the struggle for private standard dominance, alternative approaches to risk management (e.g., self-assessment of risk, independent audits and risk ranking) may be the way forward in a similar way to how insurance risks are calculated for businesses. As such, certification of standards could disappear in favor of a more general risk and insurance model for food and farming [41].

In addition to harmonizing food safety standards to reduce duplication and multiple audits, the need for global harmonization of food safety regulations is also growing with every new food safety incident [65]. Food and water borne diarrheal diseases are considered the leading causes of illness and death in less developed countries, claiming an estimated 2.2 million lives (mostly children) annually [95]. Hence, global harmonization is also a major step in ensuring that populations around the world benefit from the same degree of health protection from food borne hazards and the same standard of food safety [72].

\section{Acknowledgments}

J.M. Soon gratefully acknowledges the financial support from the Malaysia Government.

\section{References and Notes}

1. Tyrrel, S.F., J.W. Knox, and E.K. Weatherhead. "Microbiological water quality requirements for salad irrigation in the United Kingdom." Journal of Food Protection 69 (2006): 2029-35.

2. DEFRA. "Agriculture in the United Kingdom." Available online: http://www.defra.gov.uk/ statistics/foodfarm/cross-cutting/auk/ (accessed on 18 July 2011).

3. “Food safety certification.” FAO, 2006. Available online: ftp://ftp.fao.org/docrep/fao/008/ag067e/ ag067e00.pdf (accessed on 5 March 2010).

4. “Information for primary producers." FSA, 2010. Available online: http://www.food.gov.uk/ foodindustry/regulation/hygleg/hygleginfo/primprodqanda/ (accessed on 5 April 2010).

5. Jacques Trienekens, and Peter Zuurbier "Quality and safety standards in the food industry, Developments and challenges." Food Safety and Quality 113 (2008): 107-22.

6. Cooter, R., and Rorie Fulton. "Food matters: Food safety research in the UK public sector, 19171990." Food Industry Journal 4 (2001): 251-61.

7. Whitney, C.R. "Food scandal adds to Belgium's image of disarray." New York Times, 9 June 1999. Available online: http://www.nytimes.com/1999/06/09/world/brussels-journal-foodscandal-adds-to-belgium-s-image-of-disarray.html?pagewanted=1 (accessed on 25 March 2010).

8. Clephan M. Palmer. "A week that shook the meat industry: The effects on the UK beef industry of the BSE crisis." British Food Journal 98 (1996): 17-25.

9. Peter Shears, Fran Zollers, and Sandy Hurd. "Food for thought: What mad cows have wrought with respect to food safety regulation in the EU and UK." British Food Journal 103 (2001): 63-87.

10. Knowles, T.G., D. Farrington, and S.C. Kestin. "Mercury in UK Imported Fish and Shellfish and UK-Farmed Fish and their Products.” Food Additives and Contaminants 20 (2003): 813-18. 
11. Xiapfang Pei, Annuradha Tandon, Anton Alldrick, Liana Giorgi, Wei Huang, and Ruijia Yang. "The China melamine milk scandal and its implications for food safety regulation." Food Policy 36 (2011): 412-20.

12. CDC. "Multistate outbreak of salmonella infections associated with peanut butter and peanut butter-containing products-United States, 2008-2009." Morbidity and Mortality Weekly Report 58 (2009): $1-6$.

13. FDA. "Foodborne outbreak potentially associated with papaya distributed by Agromod Produce, Inc, 2011.” Available online: http:/www.fda.gov/newsevents/newsroom/pressannouncements/ ucm265166.htm (accessed on 20 August 2011).

14. EFSA. "EFSA publishes report from its Task Force on the E. coli O104:H4 outbreaks in Germany and France in 2011 and makes further recommendations to protect consumers." European Food Safety Authority, 5 July 2011. Available online: http://www.efsa.europa.eu/en/press/news/ 110705.htm (accessed on 20 February 2012).

15. Jean-Marie Codron, Eric Giraud-Héraud, and Louis-Georges Soler. "Minimum quality standards, premium private labels and European meat and fresh produce retailing." Food Policy 30 (2005): 270-83.

16. Linda Fulponi. "Private voluntary standards in the food system: The perspective of major food retailers in OECD countries." Food Policy 31 (2006): 1-13.

17. Spencer Henson, and Thomas Reardon. "Private agri-food standards: Implications for food policy and the agri-food system." Food Policy 30 (2005): 241-53.

18. Steve Jaffee, and Oliver Masakure. "Strategic use of private standards to enhance international competitiveness: Vegetable exports from Kenya and elsewhere.” Food Policy 30 (2005): 316-33.

19. Denise Y. Mainville, Decio Zylbersztajn, Elizabeth M.M.Q. Farina, and Thomas Reardon. "Determinants of retailers' decisions to use public or private grades and standards: Evidence from the fresh produce market of São Paulo, Brazil." Food Policy 30 (2005): 334-53.

20. Okezie. I. Aruoma. "The impact of food regulation on the food supply chain." Toxicology 221 (2006): 119-27.

21. Spencer Henson, and J. Humphrey. "The impacts of private food safety standards on the food chain and on public standard-setting processes." Joint FAO/WHO Food Standards program, Codex Alimentarius Commission. Thirty-second session, Rome, Italy, 29 June-4 July 2009. Available online: ftp://ftp.fao.org/Codex/CAC/CAC32/al329Dbe.pdf (accessed on 16 March 2010).

22. Gregory D. Orriss, and Anthony J. Whitehead. "Hazard analysis and critical control point (HACCP) as a part of an overall quality assurance system in international food trade." Food Control 11 (2000): 345-51.

23. Boutrif, E. "The new role of Codex Alimentarius in the context of WTO/SPS agreement." Food Control 14 (2003): 81-88.

24. Elizabeth M.M.Q. Farina, and Thomas Reardon. "Agrifood grades and standards in the extended Mercosur: Their role in the changing agrifood system." American Journal Agricultural Economy 82 (2000): 1170-76.

25. Steven Jaffee. "From challenge to opportunity: Transforming Kenya's fresh vegetable trade in the context of emerging food safety and other standards in Europe." Agricultural and Rural 
Development Discussion Paper 2, 2003; pp. 1-76. Available online: http://www-wds.worldbank. org/external/default/WDSContentServer/WDSP/IB/2005/01/24/000112742_20050124135734/Re ndered/PDF/310100revised0ARD1DP11KE.pdf (accessed on 5 January 2013).

26. Arvanitoyannis, I.S.; Kassaveti, A. "HACCP and ISO 22000-A comparison of the two systems." In HACCP and ISO 22000: Application to Foods of Animal Origin. Edited by Arvanitoyannis, I.S.; Oxford: Wiley-Blackwell Limited, 2009, pp. 3-45.

27. EUROPA. "Food Safety_from the farm to the fork." Available online: http://ec.europa.eu/food/ food/index_en.htm (accessed 5 March 2010).

28. USDA. "United States Department of Agriculture Economic Research Service. Country-of-origin Labelling." Available online: http://www.ers.usda.gov/features/cool/ (accessed on 24 March 2010).

29. Jill E. Hobbs, Andrew Fearne, and John Spriggs. "Incentive structures for food safety and quality assurance: An international comparison.” Food Control 13 (2002): 77-81.

30. Lee, Grace Chia-Hui. "Private food standards and their impacts on developing countries." European Commission DG Trade Unit G2. Available online: http://trade.ec.europa.eu/doclib/ docs/2006/november/tradoc_127969.pdf (accessed on 13 March 2010).

31. Andrew Fearne. "The evolution of partnerships in the meat supply chain: Insights from the British beef industry." Supply Chain Management: An International Journal 3 (1998): 214-31.

32. Sencer Henson. "The role of public and private standards in regulating international food markets.” Journal of International Agricultural Trade Development 4 (2008): 63-81.

33. David E. Bell, and Mary Shelman. "GlobalGAP: Food safety and private standards." Harvard Business School, 5 January 2009. Available online: http://hbsp.harvard.edu/ (accessed on 13 September 2011).

34. Philip Leat, Pamela Marr, and Ceri Ritchie. "Quality assurance and traceability - the Scottish agri-food industry's quest for competitive advantage." Supply Chain Management: An International Journal 3 (1998):115-17.

35. Spencer Henson, Oliver Masakure, and David Boselie. "Private food safety and quality standards for fresh producer exporters: The case of Hortico Agri systems, Zimbabwe." Food Policy 30 (2005): 371-84.

36. Thomas Reardon, and Julio A. Berdegué. "The rapid rise of supermarkets in Latin America: Challenges and opportunities for development." Development Policy Review 20 (2002): 371-88.

37. Christine E. Boisrobert, Keener, L., and Huub L.M. Lelieveld. "The global harmonization initiative." In Ensuring Global Food Safety: Exploring Global Harmonization. Edited by Christine E. Boisrobert, Aleksandra Stjepanovic, Sangsuk Oh, Huub L.M. Lelieveld. London: Academic Press, 2010, pp. 71-90.

38. Thomas Reardon, Jean-Marie Codron, Lawrence Busch, James Bingen, and Craig Harris. "Global change in agrifood grades and standards: Agribusiness strategic responses in developing countries.” International Food and Agribusiness Management Review 2 (2001): 421-35.

39. van der Meulen, B.M.J. "Development of food legislation around the world." In Ensuring Global Food Safety: Exploring Global Harmonization. Edited by Christine E. Boisrobert, Aleksandra Stjepanovic, Sangsuk Oh, Huub L.M. Lelieveld. London: Academic Press, 2010, pp. 5-69. 
40. Daniele Giovannucci, and Thomas Reardon. "Understanding grades and standards - and how to apply them." In A Guide to Developing Agricultural Markets and Agro-enterprises. Edited by Giovannucci, D. Washington: The World Bank, 2001, pp. 1-16. Available online: http://mpra.ub.unimuenchen.de/13549/1/UNDERSTANDING_GRADES_AND_STANDARDS.p df (accessed on 8 March 2010).

41. Baines, R.N. "Quality and safety standards in food supply chains." In Delivering Performance in Food Supply Chains. Edited by C. Mena, G. Stevens. Cambridge: Woodhead Publishing Limited, 2010, pp. 303-23.

42. UNCTAD. "Challenges and opportunities arising from private standards on food safety and environment for exporters of fresh fruit and vegetables in Asia: Experiences of Malaysia, Thailand and Vietnam." United Nations Conference on Trade and Development, New York and Geneva, 2007. Available online: http://www.unctad.org/en/docs/ditcted20076_en.pdf (accessed on 7 March 2010).

43. Gary Gereffi, and Joonkoo Lee. "A global value chain approach to food safety and quality standards." Global Health for Chronic Disease Prevention Working Paper Series, 2009, pp. 1-52. Available online: http://www.cggc.duke.edu/pdfs/GlobalHealth/Gereffi_Lee_GVCFoodSafetyl_ 4Feb2009.pdf (accessed on 9 March 2010).

44. Freshcare. "Freshcare: The national on-farm assurance program." The National On-Farm Assurance Program for the Australian Fresh Produce Industry, 2009. Available online: http://www.freshcare.com.au/ (accessed on 23 March 2010).

45. New Zealand GAP. "New Zealand Good Agricultural Practices." 2009. Available online: http://www.newzealandgap.co.nz/index.html (accessed on 23 March 2010).

46. Spencer Henson, and James Northen. "Economic determinants of food safety controls in supply of retailer own-branded products in United Kingdom.” Agribusiness 14 (1998): 113-26.

47. Thomas Herzfeld, Larissa S. Drescher, and Carola Grebitus. "Cross-national adoption of private food quality standards." Food Policy 36 (2011): 401-11.

48. UNCTAD. "Food safety and environmental requirements in export markets - friend or foe for producers of fruit and vegetables in Asian developing countries." United Nations Conference on Trade and Development, New York and Geneva, 2007. Available online: http://www.unctad.org/ en/docs/ditcted20068_en.pdf (accessed on 17 March 2010).

49. UNCTAD. "Private-sector standards and national schemes for Good Agricultural Practices: Implications for exports of fresh fruit and vegetables from sub-Saharan Africa." Experiences of Ghana, Kenya and Uganda. United Nations Conference on Trade and Development, Geneva, 2008. Available online: http://www.unctad.org/trade_env/test1/publications/UNCTAD_DITC_ TED_2007_13.pdf (accessed on 17 March 2010).

50. Catherine Dolan, and John Humphrey. "Governance and trade in fresh vegetables: The impact of UK supermarkets on the African horticulture industry." Journal of Development Studies 37 (2000): 147-76.

51. Andrew Graffham, Esther Karehu, and James MacGregor. "Impact of EurepGAP on small-scale vegetable growers in Kenya." Fresh Insights 6 (2007): 1-78. Available online: http://www.dfid.gov.uk/r4d/PDF/Outputs/EcoDev/60506fresh_insights_6_EurepGapKenya.pdf (accessed on 5 January 2013). 
52. The World Bank. "Food Safety and Agricultural Health Standards: Challenges and Opportunities for Developing Country Exports." Report No. 31207. Poverty Reduction and Economic Management Trade Unit and Agriculture and Rural Development Department: Washington, DC, USA, 10 January 2005. Available online: http://siteresources.worldbank.org/INTRANETTRADE/ Resources/Topics/Standards/standards_challenges_synthesisreport.pdf (accessed on 17 March 2010).

53. FSA. "Consumer attitudes to food standards: Wave 8." UK Report Final, 2008. Available online: http://www.food.gov.uk/multimedia/pdfs/cas2007ukreport.pdf (accessed on 31 January 2011).

54. Linda Fulponi. "Private standards and the shaping of the agro-food system." Regional Meeting on Agricultural Trade and Development in Southeast Asian Countries, 2005. Available online: http://www.adb.org/Documents/events/2005/atd/fulponi.pdf (accessed on 19 March 2010).

55. Heather Pickett. "Supermarkets and farm animal welfare: Raising the standard." A report for Compassion in World Farming Trust, 2006. Available online: http:/www.ciwf.org.uk/includes/ documents/cm_docs/2008/s/supermarketsurvey2005.pdf (accessed on 19 July 2011).

56. Tom Fox, and Bill Vorley. "Stakeholder accountability in the UK supermarket sector. Final report of the 'Race to the Top' project." International Institute for Environment and Development, 2004. Available online: http://www.racetothetop.org/documents/RTTT_final_report_full.pdf (accessed on 19 July 2011).

57. James R. Northen. "Using farm assurance schemes to signal food safety to multiple food retailers in the U.K." International Food Agribusiness Management Review 4 (2001): 37-50.

58. Monaghan, J.M., Thomas, D.J.I., Goodburn, K., and Hutchison, M.L. "A review of the published literature describing foodborne illness outbreaks associated with ready to eat fresh produce and an overview of current UK fresh produce farming practices." Food Standards Agency Project B17007, 2008, pp. 1-222. Available online: http://www.foodbase.org.uk/admintools/ reportdocuments/340-1-596_B17007_Final_Published_Report.pdf (accessed on 5 January 2013).

59. James M. Monaghan. United Kingdom and European approach to fresh produce food safety and security. HortTechnology 16 (2006): 559-62.

60. Matthew Gorton, Vlade Zarić, Philip Lowe, and Steve Quarrie. "Public and private agrienvironmental regulation in post-socialist economies: Evidence from the Serbian Fresh Fruit and Vegetable Sector." Journal of Rural Studies 27 (2011): 144-52.

61. "METRO tightens requirements on fruit/veg residues." Planet Retail, 2007. Available online: http://www1.planetretail.net/ (accessed on 5 January 2013).

62. Gulati, A., Minot, N., Delgado, C., and Bora, S. "Growth in high-value agriculture in Asia and the emergence of vertical links with farmers." In Global Supply Chains, Standards and the Poor: How the Globalization of Food Systems and Standards Affects Rural Development and Poverty. Edited by Swinnen, J.F.M. Oxon; CABI, 2007, pp. 91-108.

63. Julien, D.M. "Supplier safety assessment in the food supply chain." In Delivering Performance in the Food Supply Chains. Edited by Mena, C., Stevens, G. Cambridge: Woodhead Publishing Limited, 2010; pp. 62-83.

64. Henson, Spencer, and Neal H. Hooker. "Private sector management of food safety: Public regulation and the role of private controls." International Food and Agribusiness Management Review 4 (2001): 7-17. 
65. Lelieveld, H. "Progress with the global harmonization initiative." Trends Food Science Technology 20 (2009): S15-S19.

66. Lewis, Kathleen Anne, John Tzilivakis, Andrew Green, Douglas Warner, and Adele Coles. "Farm assurance schemes: Can they improve farming standards?" British Food Journal 110 (2008): 1088-105.

67. Baines, R.N., and Davies, W.P. "Building trust through food assurance." Presented at the IAMA World Food and Agribusiness Congress, Building Trust in the Agro-Food System, Florence, Italy, June 1999; pp. 13-16.

68. Hughes, D. Breaking with Tradition: Building Partnerships and Alliances in the European Food Industry. Ashford: Wye College, 1994.

69. "BRC global standards.” BRC, 2011. Available online: http://www.brcdirectory.com (accessed on 18 July 2011).

70. Hatanaka, Maki, Carmen Bain, and Lawrence Busch. "Third-party certification in the global agrifoodsystem." Food Policy 30 (2005): 354-69.

71. Havinga, Tetty. "Private regulation of food safety by supermarkets." Law Policy 28 (2006): 515-33.

72. Fulponi, L. "The globalization of private standards and the agri-food system." In Global Supply Chains, Standards and the Poor: How the Globalization of Food Systems and Standards Affects Rural Development and Poverty. Edited by Johan F.M. Swinnen. Oxon: CABI, 2007; pp. 5-18.

73. Barrett, H.R., Browne, A.W., Harris, P.J.C., and Cadoret, K. "Organic certification and the UK market: Organic imports from developing countries.” Food Policy 27 (2002): 301-18.

74. Martinez, M.G., and Bañados, F. "Impact of EU organic product certification legislation on Chile organic exports." Food Policy 29 (2004): 1-14.

75. OECD. "Working party on agricultural policies and markets." Private standard schemes and developing country access to global value chains: Challenges and opportunities emerging from four case studies. Organization for Economic Co-operation and Development, 2006; pp. 1-24. Available online: http://www.olis.oecd.org/ (accessed on 13 March 2010).

76. Garcia Martinez, M., and Poole, N. "The development of private fresh produce safety standards: Implications for developing Mediterranean exporting countries." Food Policy 29 (2004); 229-55.

77. Henson, Spencer, and Steven Jaffee. "Food safety standards and trade: Enhancing competitiveness and avoiding exclusion of developing countries." The Europe Journal Development Research 18 (2006): 593-621.

78. Eijlander, P. "Possibilities and constraints in the use of self-regulation and co-regulation in legislative policy: Experience in The Netherlands-lessons to be learned for the EU?" Electronic Journal of Comparative Law 9 (2005): 1.

79. Verbruggen, Paul "Does Co-regulation strengthen EU legitimacy?" European Law Journal 15 (2009): 425-41.

80. Garcia Martinez, M., Fearne, A., Caswell, J.A., Henson, S. "Co-regulation as a possible model for food safety governance: Opportunities for public-private partnerships.” Food Policy 32 (2007): 299-314.

81. Gunningham, N., and Rees, J. "Industry self-regulation: An institutional perspective." Law Policy. 19 (1997): 363-414. 
82. Núñez, Javier "Can self-regulation work? A story of corruption, impunity and cover-up.” Journal of Regulatory Economics 31 (2007): 209-33.

83. Fares, M., and Rouviere, E. "The implementation mechanisms of voluntary food safety systems." Food Policy 35 (2010): 412-18.

84. Rouvière, E., Soubeyran, R., and Bignebat, C. "Heterogeneous effort in voluntary programs on food safety: theory and evidence from the French import industry of fresh produce." European Review of Agricultural Economics 37 (2010): 479-99.

85. Rouvière, E., and Caswell, J.A. "From punishment to prevention: A French case study of the introduction of co-regulation in enforcing food safety." Food Policy 37 (2012): 246-54.

86. "Global Food Safety Initiative: Frequently asked questions." GFSI, 2008. Available online: http://www.mygfsi.com/index.php?option=com_content\&view=article\&id=10\&Itemid=57 (accessed on 10 March 2010).

87. GFSI Guidance Document, 6th ed. GFSI, 2012, Available online: http://www.mygfsi.com/ gfsifiles/GFSI_Guidance_Document_Sixth_Edition_Version_6.2.pdf (accessed on 5 January 2013).

88. GFSI recognized schemes, GFSI 2012. Available online: http://www.mygfsi.com/about-gfsi/gfsirecognised-schemes.html (accessed on 25 November 2012).

89. "Private standards in the United States and European Union markets for fruit and vegetables." Implications for developing countries. FAO, 2007. Available online: ftp://ftp.fao.org/docrep/ fao/010/a1245e/a1245e00.pdf (accessed 18 March 2010).

90. McCluskey, J.J. "Public and private food quality standards: Recent trends and strategic incentives." In Global Supply Chains, Standards and the Poor. How the Globalization of Food Systems and Standards Affects Rural Development and Poverty. Edited Johan F. M. Swinnen. Oxon: CABI, 2007, pp. 19-24.

91. Rozan, Anne, Anne Stenger, and Marc Willinger. "Willingness-to-pay for food safety: An experimental investigation of quality certification on bidding behavior." European Review of Agricultural Economics 31 (2004): 409-25.

92. Busch, Lawrence, and Carmen Bain. "New! Improved? The transformation of the global agrifood system.” Rural Sociology 69 (2004): 321-46.

93. Dickinson, David L., and DeeVon Bailey. "Meat traceability: Are U.S. consumers willing to pay for it?" Journal of Agricultural and Resource Economics 27 (2002): 348-64.

94. WHO. "Food safety." Geneva: World Health Organization, 2012. Available online: http://www.who.int/foodsafety/en/ (accessed on 6 April 2012).

95. Motarjemi, Y., van Schothorst, M., and Käferstein, F. "Future challenges in global harmonization of food safety legislation." Food Control 12 (2001): 339-46.

(C) 2013 by the authors; licensee MDPI, Basel, Switzerland. This article is an open access article distributed under the terms and conditions of the Creative Commons Attribution license (http://creativecommons.org/licenses/by/3.0/). 